\title{
Development and Analysis of Sorghum Crackers
}

\section{*P. Ashwitha Reddy, G. Pranusha, G. Laxmikanth Rao, A. Naveen Reddy}

Department of Food Technology and management, Loyola Academy Degree and PG College, Secunderabad, Telangana, India

\section{ABSTRACT}

Bakery industry is the major food processing industry in India and stands second position in the manufacture of biscuits. Bakery products are the most popular food products consumed by all age groups. The demand for bakery products is increasing in day today life because of easy availability and ready to eat convenient products having better shelf-life. Crackers are crisp baked products, chemically leavened or fermented. These are light in weight with longer shelf life. Now a day's millets are gaining popularity. In the development of sorghum crackers product, the main ingredients used are sorghum, refined wheat flour and basil leaf powder. Refined wheat flour is added in proportions to obtain soft, crispy, light fermented crackers as they cannot be made with whole sorghum flour because it is gluten free and posses less binding nature resulting in harder and heavier product. In general, the higher the gluten content in the wheat the higher the protein content of the flour. The higher the protein content of flour, the better is its ability to trap carbon dioxide gas giving lighter weight to biscuit. In the present study related to product development, sorghum crackers are developed by using sorghum flour and basil leaf powder in different variations. To acquire the beneficial properties of basil, the leaves are vacuum dried, powdered and incorporated in the product. On the whole, the nutritional aspect is increased by developing crackers with sorghum flour and basil leaves powder. Different variations are developed based on refined wheat flour and sorghum flour are 50(S):50(RWF), 60(S):40(RWF), 70(S):30(RWF) and basil powder is taken in same amount for all the variations. By laboratory evaluation of (chemical and sensory) 70(S):30(RWF) variant has got the highest acceptance.

Keywords : Sorghum, Basil leaf powder, Refined wheat flour (RWF), Ferment.

\section{INTRODUCTION}

In India, bakery industry is considered as one of the major food processing industry. India stands second in manufacturing of biscuits, first being USA. Bakery products are consumed by all age groups. They are gaining popularity as processed foods because of their convenience, ready to eat and good shelf life.

Crackers are a category of crisp baked products, chemically leavened or fermented. Soda crackers, or saltines are a traditional type of fermented cracker, produced from laminated dough.
Snack crackers are prepared by laminating dough with added flavouring and less fermentation time.

The term cracker can be used when the baked product has a cereal base where the proportion should be at least $60 \%$ and a low moisture content of $1-5 \%$ which is the distinguishing factor. Crackers usually have a higher fat content than other baked products and a longer shelf life. Crackers are used as a base for savoury toppings most commonly cheese and tomato but they may also have enough flavour from tasty coatings to be eaten alone. 
Their low moisture content was a desirable feature for better shelf-life as there was no medium for mould growth. This property of low moisture content factor makes the crackers to have a long shelf life making them a very versatile and desirable product.

\section{Types of crackers:}

1. Fermented - For example: soda crackers, saltines and cream crackers.

2. Chemically leavened - For example: snack cracker.

As consumer demand strengthens for versatile, healthy ancient grains, sorghum's popularity is seeing resurgence. With its wonderful nutty taste, sorghum is a terrific substitute for traditional grains consumed in everyday diets. Sorghum is an excellent source of energy. The consumer food industry is a growing marketplace for sorghum. With so many healthy benefits packed in every delicious grain, consumers are finding creative ways to use sorghum in recipes for breakfast, lunch, dinner and even snacks.

In this study,crackers are developed by using $70 \%$ of sorghum flour and basil leaf powder. Due to the presence of sorghum and basil leaf powder the nutritional content of the product is increased.

Considering this nutritional profile, crackers were improved by using sorghum flour and basil powder. There is significance increase in protein, fibre and iron.

As sorghum is gluten free and it is used in larger amounts, gluten content is reduced and fibre content is also increased by adding basil powder in varying amounts for different proportions.

Different variations based on refined wheat flour and sorghum flour are 50(S):50(RWF), 60(S):40(RWF), 70(S):30(RWF). And basil powder is taken in same amount for all the variations.

\section{Objectives:}

The present study was carried out with the following objectives:

- To standardize the formulation for the preparation of product based on sensory and textural characteristics.

- To increase the nutritional value of the product.

- To make traditional food ingredients more appealing and palatable.

- To make the regular snacks healthier.

\section{METHODS AND MATERIAL}

\section{Materials}

Raw materials:

Sorghum, Refined wheat flour, Basil leaves, Active dry yeast, Sugar, Salt, Ammonium bicarbonate

\section{Raw materials procurement:}

Sorghum, Refined wheat flour,Active dry yeast(Blue bird), Butter(Amul),Sugar, Salt, Ammonium bicarbonate were procured from the Retail Store in Hyderabad.

\section{Methods}

\section{Processing of Raw material:}

\section{Sorghum Flour:}

Sorghum grains are milled by miller with sieve size-2, in the laboratory at Loyola academy, Hyderabad.

\section{Basil Powder:}

Basil leaves(Rama Tulasi) are collected from a rural area of Kukunoorpally village of Siddipet District which comes under Telangana state. The leaves are cleaned thoroughly and dried in vacuum oven (Food technology laboratory at Loyola Academy) where moisture is removed under vacuum without major discolouration and nutrient loss. The dried leaves are powdered using pistle and mortar and sieved.

\section{Vacuum Oven:}

The vacuum dryer is an equipment used for drying of the heat sensitive and hygroscopic food materials. 
At the pressure of about 0.03 to 0.06 bars vacuum oven is operated generally. At this pressure water boils at 25 -35 degree centigrade.

\section{Principle:}

In vacuum dryer material is dried by the principle or applications of vacuum. The water boils at a lower temperature when the pressure is lowered by creating the vacuum, evaporation of water takes place faster.

\section{FORMULATION OF CRACKERS :}

Table 1

\begin{tabular}{|l|c|c|c|}
\hline \multirow{2}{*}{ INGREDIENTS } & \multicolumn{3}{|c|}{ FORMULATIONS } \\
\cline { 2 - 4 } & 1 & 2 & 3 \\
\hline SORGHUM & 50 & 60 & 70 \\
\hline $\begin{array}{l}\text { REFINED WHEAT } \\
\text { FLOUR }\end{array}$ & 50 & 40 & 30 \\
\hline BASIL POWDER & 2 & 2 & 2 \\
\hline YEAST & 1.5 & 1.5 & 1.5 \\
\hline SALT & 1 & 1 & 1 \\
\hline SUGAR & 2 & 2 & 2 \\
\hline $\begin{array}{l}\text { AMMONIUM } \\
\text { BICARBONATE }\end{array}$ & 1 & 1 & 1 \\
\hline BUTTER & 6.5 & 6.5 & 6.5 \\
\hline WATER & 40 & 40 & 40 \\
\hline
\end{tabular}

\section{PREPARATION OF CRACKERS:}

"Sponge and Dough" method is followed for the preparation of crackers. There are two stages in this method. (i) Preparation of sponge (ii) preparation of dough.

For sponge, Yeast is activated by using warm water and sugar which acts as food for yeast to grow and allow it to rest. Add this starter culture to $50 \%$ of sorghum and refined wheat flour and knead it to smooth dough with required water. Keep it aside in warm condition for the fermentation to occur.
For Dough, the sponge is added to the remaining ingredients like sorghum flour, salt, sugar, butter, ammonium bicarbonate, basil powder mixed and formed into dough and allow it for second fermentation. The fermented dough is sheeted to the thickness of about $1 \mathrm{~mm}$ and cut into circular shape by using a mould, butter is greased and salt is sprinkled on the surface then docking is done. Baked at $150^{\circ} \mathrm{C}$ for $10-12$ minutes. The baked crackers are cooled to room temperature and packed in metallised polyethylene pouches.

\section{Process flow chart:}

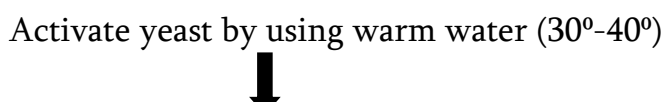

Add this starter culture to sorghum flour ( $50 \%$ of the total quantity of flour)

Knead it to smooth dough (by adding required amount of water)

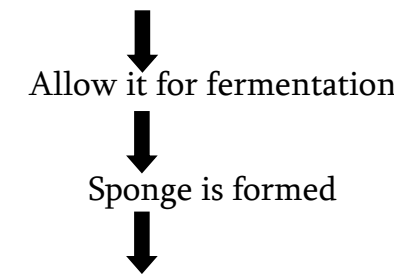

Add the remaining ingredients to the sponge (50\% SF, RWF, basil powder, salt, butter, ammonium

$$
\text { bicarbonate) }
$$

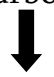

knead well and prepare a dough by adding water

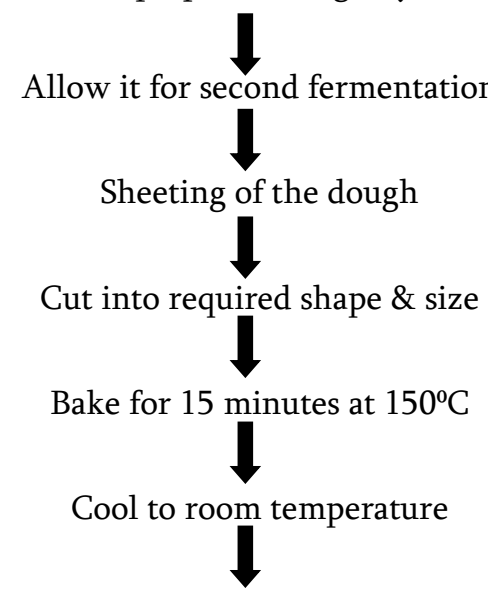

Packed in metallised polyethylene 


\section{RESULTS AND DISCUSSION}

In contrast to the regular crackers (with RWF) the product is developed by decreasing the quantity of RWF and replacing it with sorghum flour, consisting of high nutritional value compared to other plain crackers.

The nutritional and healthy facts of basil are incorporated, hence enriching the value of the product along with nutritive aspects.

Due to the addition of sorghum and basil, the crackers obtain the fibre aspect. The fat/ butter quantity is also very less compared to regular crackers. On the whole, the nutritional aspect is increased by developing crackers with sorghum flour and basil leaves powder.

\section{QUALITY ANALYSIS}

Results for $1^{\text {st }}$ variant $50: 50$ (S : RWF)

\begin{tabular}{|l|c|}
\hline Parameters & Result \\
\hline Moisture \% & 3.9 \\
\hline Ash \% & 1.4 \\
\hline Sugars \% & 0.10 \\
\hline Carbohydrates \% & 38.64 \\
\hline Fibre \% & 0.42 \\
\hline Protein \% & 4.82 \\
\hline Fat \% & 10.4 \\
\hline
\end{tabular}

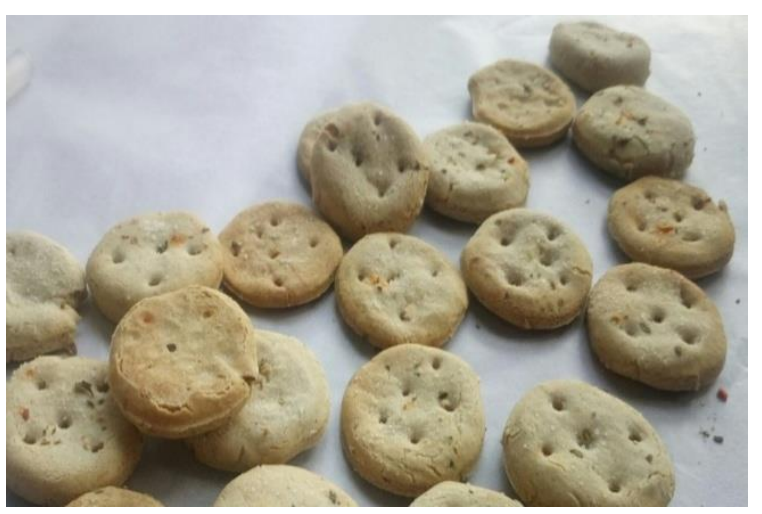

Figure 1
Results for $2^{\text {nd }}$ variant : $60: 40$ (S : RWF)

\begin{tabular}{|l|c|}
\hline Parameters & Result \\
\hline Moisture \% & 3.7 \\
\hline Ash \% & 1.6 \\
\hline Sugars \% & 0.12 \\
\hline Carbohydrates \% & 42.58 \\
\hline Fibre \% & 0.51 \\
\hline Protein \% & 6.23 \\
\hline Fat \% & 10.6 \\
\hline
\end{tabular}

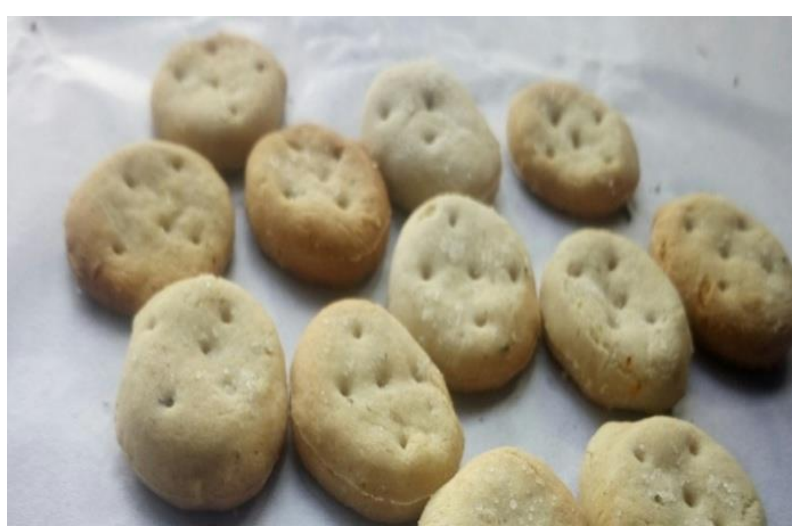

Figure 2

Results for $3^{\text {rd }}$ variant 70 : 30 (S : RWF)

\begin{tabular}{|l|c|}
\hline Parameters & Result \\
\hline Moisture \% & 2.5 \\
\hline Ash \% & 1.2 \\
\hline Sugars \% & 0.09 \\
\hline Carbohydrates \% & 58.68 \\
\hline Fibre \% & 0.92 \\
\hline Protein \% & 7.25 \\
\hline Fat \% & 9.4 \\
\hline
\end{tabular}




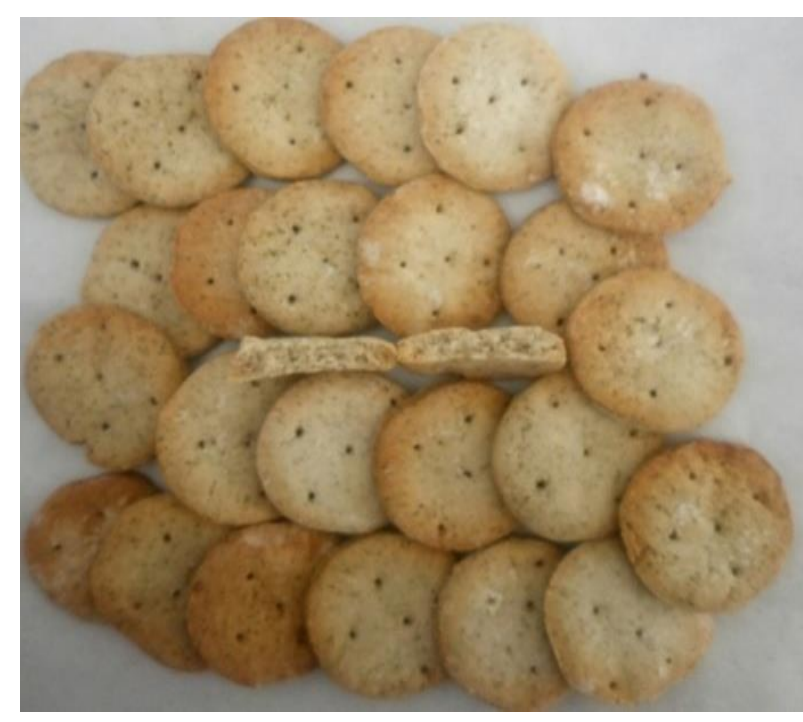

Figure 3

\section{Carbohydrates:}

The carbohydrate in crackers comes from the sucrose or sugar. It also comes from the flour. Average carbohydrate content in regular crackers is $72-78 \%$ but in this variation it is 58\% (snack crackers).

\section{Protein:}

The crackers developed with sorghum flour contains $7.25 \%$ protein ( $3^{\text {rd }}$ variant) than other two variants ranging from $4-6 \%$.

Fat:

The fat content in the crackers ranges from $9-10 \%$ in the 3 variants. The fat used also adds to the fat percentage variation. Butter is used in the sorghum crackers.

Ash:

Ash indicates minerals such as mineral content and leavening agents (chemical leavening agents) used. General saltine and snack crackers averaged about 3\% ash. Sorghum crackers contain about $1.2-1.6 \%$ ash content.

\section{Moisture:}

Crackers contain less moisture compared to other baked products. Snack crackers are fermented, proofed and baked. During baking maximum amount of moisture is evaporated hence, crackers are light, crunchy with low moisture content. Sorghum crackers contain about 2.5- $3.9 \%$ moisture, which helps to store for long duration. Appropriate and suitable packaging which controls moisture absorption adds to increase in shelf life.

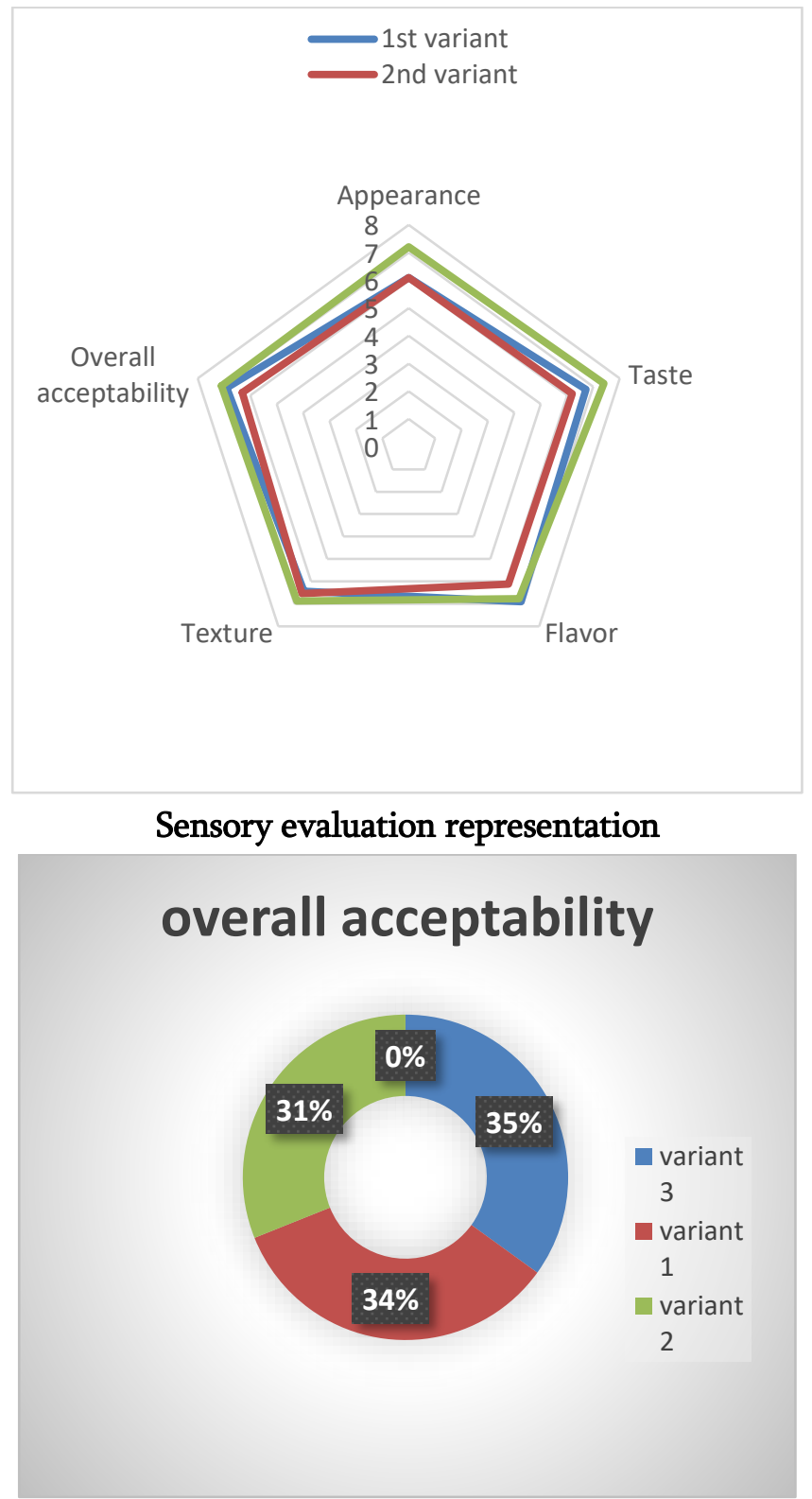

Overall acceptability of the product variations.

\section{CONCLUSION}

As stated in the objectives, the 3rd variant formulation 70:30 (S:RWF) is standardized based on sensory and nutritional analysis. As sorghum is in higher proportion, its grainy taste is accepted by most of the panel members. Generally sorghum and basil are not consumed because of their taste, which is not acceptable by many consumers, keeping this in mind product is formulated in an appealing way, where 
product does not give any off flavour yet providing palatable flavour and nutritious. As a variant with high sorghum is accepted, traditional taste and nutritional profile are achieved making the product healthier.

\section{REFERENCES}

[1]. AOAC 1971: Official method of analysis of the association of official analytical chemist. pp. 212.

[2]. AnomaChandrasekara and FereidoonShahidi., Bioactivities and Antiradical Properties of Millet Grains and Hulls.J. Agric. Food Chem. 2011, 59, 9563-9571.

[3]. Dayakar Rao, B., Rao,MH,Karthikeyan,K., Shashidhar Reddy, CH.,Gautam V.S,.Sanjay Wanjari .S., Angadi S,S.,Seetharama.N (2005) An economic analysis of crop scenario in khalif sorghum growing areas.

[4]. Dutcosky, SD. Sensory Analysis of Foods. 2nd Ed. Curitiba: Editor Champagnat, 2007; p. 239.

[5]. Effects of malting and fermentation on the composition and functionality of sorghum flours

[6]. Onesmo N.O. Mella, Department of Food Science and Technology and Researcher, Tanzania Food and Nutrition Centre Ministry of Health and Social Welfare

[7]. Figoni, Paula (2010). How Baking Works: Exploring the Fundamentals of Baking Science (3 ed.). Wiley. ISBN 978-0470392676.-a textbook on baking and setting up a bakery

[8]. Gopalan C, Sartri BVR, Balasubramanaian SC 2001: Nutritive value of Indian Foods, Hyderabad, India.

[9]. Hoseney R C, Varriano Marston E and Dendy D A V 1981 Sorghum and Millets. PP 342. In Advances in cereal science and technology (ed Y Pomeranz) American Association of Cereal Chemist, Inc, St. Paul, MN.
[10]. Kasturiba B, Patil S J, Savitri A, Parvatikar S R and Shivanna H 1989 Cooking qualities of different sorghum varieties. Journal of Maharashtra Agricultural University 14(3): 391-392.

[11]. Kent N. (1963): Chemical Composition of Cereals. 3rd Ed. Pergamon Press, Oxford: 2748.

[12]. Mertz E T, Hassen M M, Cairns-Whittern C, Kirleis A W, Tu L and Axtell J D 1984 Pepsin digestibility of proteins in sorghum and other cereals. Proceedings of the National Academy of Science 81:1-2.

[13]. Quality of crackers By Lester Hankin, A. McLean, and J. Gordon Hanna (Bulletin 803May 1982)

[14]. Rachie, K. O. (1975). The Millets. Importance, Utilization and Outlook. Hyderabad: International Crops Research Institute for the Semi-Arid Tropics (ICRISAT).

[15]. Rooney, L.W., Sorghum and pearl millet lipids. Cereal Chemistry, 1978, 55: 584-590.

[16]. Reichert, R. D (1982). Sorghum dry milling. Pg 547 - 56 in: Sorghum in the eighties Proceedings of the international symposium Patancheru, A. P. 502324 India,ICRISAT

[17]. Sorghum and other commonly consumed grains: by ashleypruettb.s.,kansas state university, 2010 (thesis)

\section{Cite this article as :}

P. Ashwitha Reddy, G. Pranusha, G. Laxmikanth Rao, A. Naveen Reddy, "Development and Analysis of Sorghum Crackers", International Journal of Scientific Research in Science and Technology (IJSRST), Online ISSN : 2395-602X, Print ISSN : 2395-6011, Volume 6 Issue 2, pp. 26-31, March-April 2019. Available at doi : https://doi.org/10.32628/IJSRST196178 Journal URL : http://ijsrst.com/IJSRST196178 